JA: Jurnal Al-Wasath 2 No.1: 7-18

Journal homepage: https://journal.unusia.ac.id/index.php/alwasath/index

ISSN 2721-6160 (Online)

\title{
Agresifitas Supir Bus Kota Yang Beretnis Batak Dan Tingkat Kapatuhan Berlalu Lintas
}

\section{Maryam}

Universitas Nahdlatul Ulama Indonesia

\section{Muhammad}

Universitas Nahdlatul Ulama Indonesia

\begin{abstract}
Abstrak
Penelitian ini bertujuan untuk melihat gambaran perilaku agresi supir bus kota dan mengetahui hal-hal yang memicu timbulnya perilaku agresi pada supir bus kota dan korelasinya terhadp kepatuhan hukum sopir bus kota dalam berlalu lintas. Teknik pengumpulan data pada penelitian ini adalah wawancara dan observasi. Subjek penelitian pada penelitian ini adalah supir bus kota berusia sekitar 30-40 tahun yang telah bekerja sebagai supir bus minimal satu tahun dan beretnis Batak. Selain wawancara dengan subjek, peneliti juga melakukan wawancara dengan significant other yang merupakan kernet subjek. Hasil penelitian menunjukkan bahwa subjek melakukan perilaku agresi baik secara fisik, verbal, aktif, pasif dan secara langsung maupun tidak langsung, yang dipicu oleh beberapa faktor yaitu, frustrasi, stres, deindividuasi, kekuasaan dan kepatuhan, provokasi dan suhu udara. Hal tersebut yang menjadi faktor rendahnya tingkat kepatuhan hukum sopir bus dalam berlalu lintas.
\end{abstract}

Keywords:

Agresi, Supir Bus Kota, Kapatuhan, Lalu Lintas.

Corresponding Author:

Maryam

maryam@unusia.ac.id

Universitas Nahdlatul Ulama Indonesia

Muhammad

muhammadafifi@unusia.ac.id

Universitas Nahdlatul Ulama Indonesia

(C) The Author(s) 2021

DOI: 10.47776/alwasath.v2i1.171

\section{cc) 0}

CC BY: This license allows reusers to distribute, remix, adapt, and build upon the material in any medium or format, so long as attribution is given to the creator. The license allows for commercial use.

Submitted: 21 April 2021

Accepted: 22 April 2021

Online: 22 April 2021

\section{Classification \\ Conceptual Article}




\section{PENDAHULUAN}

Hukum merupakan salah satu instrumen untuk mengatur tingkah laku masyarakat dalam mengatur pergaulan hidup. Secara sosiologis hukum mengandung berbagai unsur antara lain rencana-rencana tindakan atau perilaku, kondisi dan situasi tertentu. Menurut Abdul Manan, Hukum adalah suatu rangkaian peraturan yang menguasai tingkah laku dan perbuatan tertentu dari manusia dalam hidup bermasyarakat. Hukum itu sendiri mempunyai ciri yang tetap yakni hukum merupakan suatu organ peraturan-peraturan abstrak, hukum untuk mengatur kepentingankepentingan manusia, siapa saja yang melanggar hukum akan dikenakan sanksi sesuai dengan apa yang telah ditentukan. ${ }^{1}$

Perilaku agresi tidak muncul dengan sendirinya, seringnya terjadi agresi menurut disebabkan karena terdapat kondisi-kondisi atau faktor-faktor yang mengarahkan terjadinya agresi, faktor-faktor tersebut adalah frustrasi, stres, deindividuasi, kekuasaan dan kepatuhan, kehadiran senjata, provokasi, obat-obatan, alkohol dan suhu udara. Sedangkan agresi itu sendiri didefinisikan oleh Berkowits sebagai suatu bentuk perilaku yang bertujuan melukai seseorang baik secara fisik maupun psikologis. ${ }^{2}$

Lalu Lintas dan Angkutan Jalan memiliki peran strategis dalam mendukung pembangunan. Disamping itu peran laain adlaah supaya terwujudnya integrasi nasional sebagai bagian dari upaya memajukan kesejahteraan umum sebagaimana diamanatkan oleh konstitusi. Sebagai bagian dari sistem transportasi nasional, Lalu Lintas dan Angkutan Jalan harus dikembangkan potensi dan perannya untuk mewujudkan keamanan, kesejahteraan, ketertiban berlalu lintas dan Angkutan Jalan dalam rangka mendukung pembangunan ekonomi dan pengembangan ilmu pengetahuan dan teknologi, otonomi daerah, serta akuntabilitas penyelenggaraan negara dan untuk kepentingan umum.

Seperti diketahui bahwa tidak semua masyarakat memiliki kendaraan pribadi untuk digunakan dalam menjalani aktivitasnya sehari-hari, banyak masyarakat yang menggunakan jasa angkutan umum seperti bus kota. Bila diperhatikan tidak jarang terlihat banyaknya supir bus yang mengendarai bUsnya dengan kecepatan tinggi dan menggunakan jalan tidak semestinya dengan melanggar aturan-aturan lalu-lintas seperti menurunkan dan mengangkut penumpang di tengah jalan atau mengendarai bus dengan kecepatan tinggi dengan mendahului kendaraan lain.

Kepatuhan hukum merupkan keadaan seseorang warga masyarakat yang tunduk patuh dalam satu aturan (hukum) yang berlaku, dan salah satu aturan hukum yang perlu dipatuhi adalah Undang-Undang Nomor 22 tahun 2009 Tentang Lalu lintas dan Angkutan Jalan. Namun, salah satu permasalahan yang mendasar dalam menerapkan hukum atau undang-undang lalu lintas dan angkutan jalan tersebut adalah permasalahan pada tingkat kepatuhan pengemudi angkutan kota/angkutan umum yang sering berhenti atau parkir sembarangan, bertindak ugal-ugalan, sehingga membuat jalanan menjadi macet, dan dapat membahayakan diri sendiri dan orang lain.

Profesi sebagai supir bus dijalani oleh orang-orang yang berasal dari berbagai etnis, seperti Batak, Padang, Jawa, Sunda dan Etnis-etnis lainnya. Seperti diketahui Indonesia adalah salah satu negara dengan masyarakat majemuk dilihat dari berbagai sudut dan tingkat perkembangan kebudayaan. Bagian-bagian bangsa Indonesia yang demikian banyak itu disebut kelompok etnik. ${ }^{3}$ Menurut Theodorson \& Theodorson kelompok etnik adalah suatu kelompok sosial yang memiliki tradisi kebudayaan dan rasa identitas yang sama sebagai bagian dari kelompok masyarakat yang lebih besar. Menurut Cohen kelompok etnik adalah suatu kesatuan orang-orang yang secara

\footnotetext{
${ }^{1}$ Abdul Manan, Aspek-aspek Pengubah Hukum, Jakarta : Kencana, 2006, hlm. 2.

${ }^{2}$ Koeswara, E., Agresi Manusia. Jakarta: Penerbit Eresco, 1988, hlm. 5.

${ }^{3}$ Koentjaraningrat, Manusia dan Kebudayaan di Indonesia, Jakarta : Penerbit Djambatan, 2004, hlm. 10. 
bersama-sama menjalani polah-polah tingkah laku normatif, atau kebudayaan dan yang membentuk suatu bagian dari populasi yang lebih besar, saling berinteraksi dalam kerangka suatu sistem sosial bersama seperti negara. Kesamaan pemikiran dari ketiga tokoh asing di atas adalah tentang kedudukan suku bangsa yang harus dilihat sebagai bagian dari sistem sosial yang lebih besar. ${ }^{4}$ Dan yang menjadi subyek dalam penelitian ini adalah supir sebaga profesi yang berasalah dari Suku Batak.

Jumlah penduduk etnis Batak pada tahun 2000 jumlahnya 6, 076 juta jiwa dan menjadi etnis besar kelima dengan rata-rata angka pertumbuhan penduduknya $2,31 \%$ pertahun dengan rincian : subetnis Tapanuli jumlah penduduknya 48,32\%, Toba sebesar 18,45\%, Mandailing $17,03 \%$, Karo 9,63\% dan subetnis Angkola 6,36\%. Etnis Batak yang tinggal di Jakarta lebih dari 300 ribu jiwa dan 3,61\% dari semua warga negara Indonesia di Jakarta. ${ }^{5}$

Stereotipe bahwa orang Batak tidak jauh dari supir bus dan preman pun seakan sudah kuat melekat pada masyarakat Indonesia. ${ }^{6}$ Orang Batak cenderung kasar, sembrono, tidak tahu diri, pintar omong kosong. tidak tahu malu, menyebalkan cara bicaranya keras, sembarangan ketika menggunakan jalanan umum seperti ketika sedang mengemudi, dan cenderung egois. ${ }^{7}$ Stereotipestereotipe kesukuan yang masih sering terdengar juga misalnya orang-orang Jawa dan Sunda beranggapan bahwa mereka halus dan sopan, dan bahwa orang-orang Batak kasar, suka berbicara keras, pemberang dan suka berkelahi. Tetapi orang Batak sendiri menganggap bahwa mereka pemberani, terbuka, suka berterus terang, pintar, rajin, kuat dan tegar. Mereka menganggap orangorang Jawa dan Sunda lebih halus dan spontan tetapi lemah dan tidak suka berterus terang. Apa yang orang anggap kekasaran bagi orang Batak justru kejujuran. Apa yang orang Sunda dan Jawa anggap kehalusan, bagi orang Batak adalah kemunafikan dan kelemahan. ${ }^{8}$

Hasil penelitian Warnaen menyebutkan beberapa sifat-sifat dari etnis Batak berdasarkan stereotipe dari 12 golongan etnis yang ada di Jakarta yaitu, Sunda, Jawa, Minangkabau, Batak, Minahasa, Maluku, Tionghoa, dan lain-lain dan berdasarkan 7 golongan etnis di luar Jakarta yaitu, Sunda (Bandung), Jawa (Yogyakarta), Minangkabau (Bukittinggi), Batak (Pematang Siantar), Bugis Makassar (Ujumgpandang). Minahasa (Manado) dan Maluku (Ambon). Sifat-sifat yang paling banyak mendapatkan penilninn yaitu ; agresif, emosional, kasar, keras kepala, cepat marah, ambisius dan memiliki ikatan kekeluargaan yang erat. ${ }^{9}$

Memang tidak hanya etnis Batak yang menunjukan perilaku ketika mengemudi namun karena adanya stereotipe mengenai orang Batak emosional, kasar, keras kepala, cepat marah dan ambisius maka timbul pemikiran dari penulis bahwa ada kemungkinan tingkat agresifitas pada orang orang Batak tinggi dengan adanya stereotipe stereotipe mengenai orang Batak tersebut. Berdasarkan latar belakang di atas, peneltian ini akan memberikan gambaran gambaran perilaku agresi supir bus kota yang beretnis Batak.

\section{METODOLOGI PENELITIAN}

Penelitian ini menggunakm pendekatan kualitatif dengan bentuk studi kasus. Menurut Yin studi kasus adalah salah satu metode penelitian ilmu-ilmu sosial. Secara umum, studi kasusu merupakan strategi yang lebih cocok bila pokok pertanyaan suatu penelitian berkenaan dengan how atau why. bila peneliti hanya memiliki peluang untuk mengontrol peristiwa-peristiwa yang akan

\footnotetext{
${ }^{4}$ Hidayah, Z., Ensikopledi Suku Bangsa di Indonesia. Jakarta: LP3ES, 1997, hlm. 76.

${ }^{5}$ Suryadinata, L., Arifin, E.N., \& Ananta, A., Penduduk Indonesia Etnis dan Agama dalam Era Perubahan Politik, Jakarta : LP3ES, 2003. Hlm. 100.

${ }^{6}$ Peranginangin, M.L., Orang Karo Di antara Orang Batak, Jakarta : Pustaka Sara Mido. 2004, hlm. 4.

${ }^{7}$ Jimmy, H.E.W., http://www.geocities.com/primbon2000/suku.htm. Diakses pada 17 Septe,ber 2019

8 Jimmy, H.E.W., http://www.geocities.com/primbon2000/suku.htm. Diakses pada 17 Septe,ber 2019

${ }^{9}$ Warnaen, S., Stereotipe Etnis dalam Masyarakat Multietnis. Jakarta : Mata Bangsa, 2002, hlm. 9.
} 
diselidiki, dan bilamana fokus penelitiannya terletak pada fenomena kontemporer (masa kini) di dalam konteks kehidupan nyata. 10

Menurut Poerwandari penelitian kualitatif adalah penelitian yang menghasilkan dan mengolah data yang sifatnya deskriptif, seperti transkripsi wawancara, catatan lapangan, gambar, foto, rekaman video dan lain sebagainya. Dalam penelitian kualitatif perlu menekankan pada pentingnya kedekatan dengan orang-orang dan situasi penelitian, agar peneliti memperoleh pemahaman jelas tentang relalitas dan kondisi nyata kehidupan sehari-hari.11

Kriteria subjek penelitian yang akan digunakan di dalam penelitian ini adalah supir bus kota yang berusia sekitar 30-40 tahun, yang telah bekerja sebagai supir bus minimal satu tahun dan beretnis Batak. Jumlah Subjek Penelitian Fokus penelitian kualitatif adalah pada proses dan kedalaman penghayatan subjek, sehingga penelitian kualitatif cenderung dilakukan dengan jumlah kasus sedikit. Sedangkan karakteristik prosedur pengambilan sampel pada penelitian kualitatif adalah: (1) diarahkan tidak pada jumlah sampel yang besar tetapi pada kasus-kasus tipikal sesuai kekhususan masalah penelitian: (2) tidak ditentukan secara kaku sejak awal, tetapi dapat berubah baik dalam jumlah maupun karakteristiknya: (3) tidak diarahkan pada keterwakilan (dalam arti jumlah atau peristiwa acak) melainkan pada kecocokan konteks. 12

Jenis penelitian ini termasuk penelitian deskriptif, dengan fokus penelitian yaitu mengkaji tingkat kepatuhan hukum pengemudi angkutan kota, serta analisis terhadap substansi UndangUndang Nomor 22 Tahun 2009 tentang lalu lintas dan angkutan jalan, khususnya pada pasal 3 tentang pelayanan yang aman dan tertib, dan pasal 36 tentang pemamfaatan terminal. Adapun Jenis dan sumber data dalam penelitian ini adalah: ${ }^{13}$

1) Data primer yaitu data yang diperoleh dari responden (pengemudi angkutan kota) dengan menggunakan teknik wawancara (interview) dan Observasi (pengamatan). Data ini digunakan dalam rangka pemenuhan data mengenai subjek penelitian.

2) Data sekunder yaitu data yang diperoleh melalui hasil penelusuran dan penelaah studi kepustakaan yaitu buku-buku atau referensi yang relevan dengan kajian ini.

Adapun proses analisis data yang dilakukan dalam penelitian ini akan dianalisa dengan tehnik analisa data kualitatif yang diajukan oleh Marshall Rosunan dalam manganalisa penelitian kualitatif terhadap beberapa tahapan yang perlu dilakukan. ${ }^{14}$ Tahap-tahap tersebut, pertama, mengkombinasikan data, Peneliti mendapatkan data langsung dari subjek melalui wawancara mendalam, yang dimana data direkam dengan tape recorder dibantu alat tulis lainnya. Kemudian dibuatkan transkipnya dengan mengubah hasil wawancara dari bentuk rekaman menjadi bentuk tertulis secara verbatim setelah selesai menemui subjek.

Kedua, Pengelompokkan berdasarkan kategori, tema dan pola jawaban. Dalam tahapan ini dibutuhkan pengertian yang dalam terhadap data, perhatian yang penuh dan keterbukaan terhadap hal-hal yang muncul di huar apa yang ingin digali. Berdasarkan kerangka teori dan pedoman wawancara peneliti menyusun sebuah kerangka awal analisis sebagai acuan dan pedoman dalam

\footnotetext{
${ }^{10}$ Yin, R.K, Studi Kasus Design dan Metode, Jakarta : PT. Rajagrafindo Persada, 2003, hlm. 17.

${ }^{11}$ Poerwandari, E.K., Pendekatan Kualitas dalam Penelitian Psikologi. Jakarta : Penerbit. Universitas Indonesia, 1998, hlm. 20.

${ }^{12}$ Poerwandari, E.K., Pendekatan Kualitas dalam Penelitian Psikologi. Jakarta : Penerbit. Universitas Indonesia, 1998, hlm. 33.

${ }^{13}$ Soerjono, Pengantar Penelitian Hukum, Jakarta : UI Press, 2010, hlm. 17

${ }^{14}$ Marshall, C \& Rossman, G., Designing Qualitative Research, California: Stage Publications, Inc., 1998, hlm. 17.
} 
melakukan koding Dengan podoman ini, peneliti kemudian kembali membaca transkip wawancara dan melakukan koding, melakukan pemilihan data yang relevan dengan pokok pembicaraan.

Data yang relevan diberi kode dan penjelasan singkat, kemudian dikelompokkan atau dikategorikan berdasarkan kerangka analisis yang telah dibuat. Ketiga, Menguji asumsi atau permasalahan yang ada terhadap data. Setelah kategori dan pola tergambar dengan jelas, peneliti menguji data tersebut terhadap asumsi yang dikembangkan dalam penelitian ini. Pada tahap ini kategori yang telah didapat melalui analisis ditinjau kembali berdasarkan landasan teori, sehingga dapat dicocokkan ada kesamaan antara landasan teori dapat dibuat asumsi-asumsi mengenai hubungan antara konsep-konsep dan faktor-faktonya. Keempat, Mencari alternatif penjelasan bagi data.

Setelah kaitan antara kategori dan pola data dengan asumsi terwujud, penulis masuk kedalam tahap penjelasan. Berdasarkan pada kesimpulan yang telah didapat dari kaitan tersebut, penulis perlu mencari suatu alternatif penjelasan lain tentang kesimpulan yang telah didapat. Sebab dalam penelitian kualitatif memang selalu ada alternatif penjelasan yang lain. Dari hasil analisis ada kemungkinan toanlapat hal-hal yang menyimpang dari assi ata tidak terpikirkan sebelumnya.

Dalam tahap ini akan dijelaskan dengan altamatif lain melalui refleksi atau teori-teori lain Alternatif ini akan sangan berguna pada bagian kesimpulan dan saran. Dan kelima, menulis hasil penelitian. Penulisan analisis data masing-masing subjek yang telah berhasil dikumpulkan, merupakan suatu hal yang manbantu penulis untuk memeriksa kembali apakah kesimpulan yang dibuat telah selesai.

Dalam penelitian ini. penulisan yang dipakai adalah presentasi data yang didapat yaitu penulisan data-data hasil penelitian berdasarkan wawancara dan observasi dengan tiap tiap subjek Prosesnya dimulai dari data-data yang telah diperoleh dari subjek dibaca berulang kali sampai penulis mengerti benar permasalahannya lalu dianalisis, sehingga didapatkan gambaran mengenai penghayatan yang dialami subjek. Selanjutnya dilakukan interpretasi secara keseluruhan dimana di dalamnya mencangkup keseluruhan kesimpulan dari hasil penelitian ini.

\section{HASIL DAN PEMBAHASAN}

Undang-undang No. 22 Tahun 2009 tentang Lalu Lintas dan Angkutan Jalan dibuat dengan tujuan suya penyelenggaraan lalu lintas dan angkutan jalan sesuai harapan masyarakat, sejalan dengan kondisi dan kebutuhan penyelenggaraan lalu lintas dan angkutan jalan saat ini, serta harmoni dengan Undang-undang lainnya.

Dengan menyadari pentingnya peranan transportasi, maka lalu lintas dan angkutan jalan harus ditata dalam suatu sistem transportasi nasional secara terpadu dan mampu mewujudkan tersedianya jasa transportasi yang sesuai dengan tingkat kebutuhan lalu lintas dan pelayanan angkutan yang tertib, nyaman, cepat, teratur, lancar dan dengan biaya yang terjangkau oleh daya beli masyarakat.

Untuk itu pemerintah telah mengeluarkan kebijakan di bidang transportasi darat yaitu dengan dikeluarkannya UU No. 22 Tahun 2009 tentang Lalu Lintas dan Angkutan Jalan sebagai Pengganti UU No. 14 Tahun 1992, serta Peraturan Pemerintah No. 41 Tahun 1993 tentang Angkutan Jalan yang masih tetap berlaku meskipun PP No. 41 Tahun 1993 merupakan peraturan pelaksanaan dari UU No. 14 tahun 2003 dikarenakan disebutkan dalam Pasal 324 UU No. 22 Tahun 2009 bahwa : "Pada saat Undang-Undang ini mulai berlaku, semua peraturan pelaksanaan UndangUndang Nomor 14 Tahun 1992 tentang Lalu Lintas dan Angkutan Jalan (Lembaran Negara Republik Indonesia Tahun 1992 Nomor 49, Tambahan Lembaran Negara Republik Indonesia 
Nomor 3480) dinyatakan tetap berlaku sepanjang tidak bertentangan atau belum diganti dengan yang baru berdasarkan Undang-Undang ini”.

Dalam pasal 2 dan pasal 3 Undang- Undang Lalu Lintas dan Angkutan Jalan (yang selanjutnya disingkat dengan UULLAJ) mengatur asas dan tujuan pengangkutan. Adapun Asas penyelenggaraan lalu lintas adalah diatur dalam Pasal 2 UULLAJ yakni : Lalu Lintas dan Angkutan Jalan diselenggarakan dengan memperhatikan: a) asas transparan, b) asas akuntabel, c) asas berkelanjutan, d) asas partisipatif, e) asas bermanfaat, f) asas efisien dan efektif, g) asas seimbang, h) asas terpadu dan i) asas mandiri.

Sedangkan Pasal 3 UULAJ menyebutkan mengenai tujuan dari Lalu Lintas dan Angkutan Jalan yakni:

1) Terwujudnya pelayanan Lalu Lintas dan Angkutan Jalan yang aman, selamat, tertib, lancar, dan terpadu dengan moda angkutan lain untuk mendorong perekonomian nasional, memajukan kesejahteraan umum, memperkukuh persatuan dan kesatuan bangsa, serta mampu menjunjung tinggi martabat bangsa

2) Terwujudnya etika berlalu lintas dan budaya bangsa;

3) Terwujudnya penegakan hukum dan kepastian hukum bagi masyarakat.

Dengan berlakunya UU No. 22 Tahun 2009 tersebut diharapkan dapat membantu mewujudkan kepastian hukum bagi pihak-pihak yang terkait dengan penyelenggaraan jasa angkutan, baik itu pengusaha angkutan, pekerja (sopir/ pengemudi) serta penumpang. Secara operasional kegiatan penyelenggaraan pengangkutan dilakukan oleh pengemudi atau sopir angkutan dimana pengemudi merupakan pihak yang mengikatkan diri untuk menjalankan kegiatan pengangkutan atas perintah pengusaha angkutan atau pengangkut.

Pengemudi dalam menjalankan tugasnya mempunyai tanggung jawab untk dapat melaksanakan kewajibannya yaitu mengangkut penumpang sampai pada tempat tujuan yang telah disepakati dengan selamat, artinya dalam proses pemindahan tersebut dari satu tempat ke tempat tujuan dapat berlangsung tanpa hambatan dan penumpang dalam keadaan sehat, tidak mengalami bahaya, luka, sakit maupun meninggal dunia. Sehingga tujuan pengangkutan dapat terlaksana dengan lancar dan sesuai dengan nilai guna masyarakat.

Berdasarkan hasil penelitian dapat dilihat perilaku agresi pada subjek, perilaku yang muncul yaitu, subjek sering terlibat perkelahian dengan calo, supir bus lain dan dengan pengendara mobil pribadi maupun pengendara motor. Subjek suka menjalankan bus dalam kecepatan tinggi serta menyalip mobil tau bus lain (perilaku agresi secara fisik, aktif, langsung dan vertel, aktif, Langsung). subjek juga menunjukan perilaku agresi Verbal, aktif, tidak langsung dengan mengeluarkan kata-kata kasar ketika sedang mengemudikan busnya, tiba-tiba ada bus lain, mobil pribadi dan motor menyalip bisnya. Subjek suka menyebarkan isu kepada calon penumpang bahwa busnya yang terakhir dan tidak ada bus lagi setelah itu, hal ini dilakukan dengan alasan agar subjek mendapatkan banyak penumpang (Verbal, aktif, tidak langsung).

Perilaku agresi Verbal, pasif, langsung ditunjukan subjek melalui perilaku subjek yang terkadang tidak mempedulikan orang lain yang dianggapnya tidak perlu diladeni yaitu preman terminal yang suka meminta uang kepada subjek dalam keadaan mabuk. Perilaku agresi subjek tersebut sesuai dengan teori yang dikemukakan oleh Berkowitz (dalam Prabowo \& Riyanti, 1998). Menurut Berkowitz (1993) agresi didefinisikan sebagai suatu bentuk perilaku yang bertujuan melukai seseorang baik secara fisik maupun psikologis.

Perilaku agresi yang dilakukan subjek tidak muncul dengan sendirinya. perilaku ini muncul dikarenakan beberapa faktor yaitu, frustrasi, stres. deindividuasi, kekuasaan dan kepatuhan, 
provokasi dan suhu udara. Subjek mengalami frustrasi dan stres yang disebabkan karena subjek tidak dapat memenuhi kebutuhan sehari-hari dan semakin memburuknya keadaan ekonomi subjek.

Frustrasi adalah situasi dimana individu terhambat atau gagal dalam usaha mencapai tujuan tertentu yang diinginkannya, atau mengalami hambatan untuk bebas bertindak dalam rangka mencapai tujuan (Koeswara, 1999), karena tidak dapat memenuhi tuntukan ekonomi dan subjek merasa terhalang untuk mendapatkan penghasilan bila ada bus atau mobil lain yang menyalipnya maka subjek menjadi frustasi dan subjek menjadi agresif. Menurut Engel (dalam Koeswara, 1988) stres eksternal adalah stres yang berasal dari luar individu atau lingkungan sekitar, dalam hal ini adalah sosial dan ekonomi yang berarti semakin memburuknya keadaan sosial dan ekonomi akan meningkatkan stres individu yang mengakibatkan perilaku yang lebih agresi.

Karena memburuknya keadaan ekonomi subjek maka subjek menjadi stres. Menurut Lorenz deindividuasi adalah tindakan non emosional sebagai akibat penggunaan teknik-teknik dan senjata modern. Dalam hal ini deindividuasi mempengaruhi perilaku agresi pada subjek, karena subjek merasa sebagai supir yang mengendarai bus tersebut maka subjek terkadang berperilaku tanpa mempertimbangkan keadaan penumpang. Faktor kekuasaan dan kepatuhan juga mempengaruhi perilaku agresi subjek.

Menurut Weber kekuasaan adalah kesempatan dari seseorang atau dari sekelompok orang untuk merealisasikan keinginan-keinginannya dalam tindakan komunal bahkan meskipun harus berhadapan dengan perlawanan dari seseorang atau kelompok orang lainnya yang berpartisipasi dalam tindakan komunal tersebut. Sedangkan kepatuhan adalah sikap atau tindakan menuruti atau melaksanakan keinginan dari si pemegang otoritas atau kekuasaan.

Dalam hal ini pemegang kekuasaan tersebut adalah pemilik bus. Setiap hari Subjek harus memenuhi uang setoran yang sudah ditetapkan oleh pemilik bus sehingga subjek harus mematuhinya dengan memberikan uang setoran tersebut, dengan demikian subjek sering mengendarai busnya dengan kecepatan tinggi agar subjek dapat memenuhi uang setoran tersebut.

Subjek juga suka terprovokasi oleh perilaku penumpang yang protes terhadap perilaku subjek yang menjalankan busnya dengan kecepatan tinngi sehingga subjek terkadang menunjukan perilaku agresinya terhadap penumpang. Menurut Moyer provokasi adalah ancaman baik berupa lisan ataupun sikap yang harus dihadapi dengan respon agresif untuk meniadakan bahaya yang diisaratkan oleh ancaman itu. Faktor terakhir yang menyebabkan timbulnya perilaku agresi subjek adalah suhu Indara, dimana suhu udara panas lebih dapat memicu munculnya perilaku sgresi subjek dibanding suhu udara dingin, penelitian yang dilakukan oleh Baron mencatat bahwa pada musim panas dengan mho nekara lebih dari 90 fahrenheit (sekitar 40 derajat Celsius) lebih banyak terjadi tindak kekerasan dibandingkan dengan musim-musim yang lain.

Beberapa faktor tersebut membuat subjek menjadi mudah emosional dan berperilaku agresi, apalagi bila subjek mendapat uang, hanya sedikit, ketika sampai di rumah biasanya ia disambut dengan perlakuan istrinya yang mengeluh karena uang yang didapat dari setoran suaminya itu tidak mencukupi biaya sehari-hari dan saat itulah terjadi pertengkaran yang menimbulkan perilaku agresi dan hal ini bisa berpengaruh pada subjek pada saat ia bekerja keesokan harinya, subjek menjadi mudah emosional dan suka menjalankan bus dalam kecepatan tinggi serta menyalip mobil atau bus lain, namun subjek dapat mengendalikan diri dan memikirkan keselamatan penumpang, walau subjek hanya sedikit mengurangi kecepatan busnya karena menurut subjek jika tidak demikian maka ia tidak bisa memenuhi uang setoran dan tidak dapat memenuhi kebutuhannya sehari-hari.

Pada dasarnya perilaku agresi yang timbul tidak hanya dipengaruhi oleh faktor-faktor di atas melainkan dipengaruhi pula oleh faktor budaya. Dalam budaya etnis Batak dikenal suatu adat yang bernama Dalihan Na Tolu yang memiliki tujuh nilai inti yaitu : kekerabatan, agama, hagabeon, 
hamoraan, whum dan ugari, pangayoman, dan marsisarian. Ketujuh unsur budaya tersebut masih diaplikasikan dalam kehidupan subjek sehari-hari. Dalam hal ini nilai inti dari Dalihan $\mathrm{Na}$ Tolu yang sangat berpengaruh terhadap stereotipe bahwa etnis Batak itu emosional, mudah marah, kasar, dan ambisius dan juga yang mempengaruhi timbulnya perilaku agresi pada subjek adalah uhum ugari. Uhum adalah hukum yang bagi orang Batak mutlak untuk ditegakkan dan pengakuaannya tercermin pada kesungguhan dalam penerapanya menegakkan keadilan.

Nilai suatu keadilan itu ditentukan dari ketaatan pada ugari atau perilaku serta setia dengan padan atau janji. Setiap orang Batak yang menghormati dan menjalankan uhum, ugari, dan padang akan dipandang sebagai orang Batak yang sempurna. Keteguhan pendirian pada orang Batak bermastan nilai-nilai hukum Perbuatan atau perilaku yang melanggar kesepakatan adat dan $p$ tercela dan mendapatkan sangsi hukum secara adat Oleh karena itu orane Flu Tak selalu berterus terang dan apa adanya serta tidak banyak haa-hesi, hal ini yang menyebabkan muncul stereotip bahwa orang Batak itu emonional, kasar, mudah marah, dan ambisius dan jua mempengaruhi perilaku agresi subjek. Dalam lingkungan subjek hal seperti itu dianggap waja, subjek tidak biasa dimanja dan diajarkan dengan didikan yang cenderung, otoriter dan keras serta dididik untuk mandiri.

Dalam keseharian subjek, ia diajarkan untuk dapat bertanggung jawab, karena itu bila mempunyai masalah subjek harus bisa menyelesaikannya sendiri. Dalam melakukan pembicaraan orang Batak melakukan secara terbuka, yang pada dasarnya merupakan upaya untuk mengangkat masalah yang harus dibicarakan terbuka atau eksplisit. Dalam kebiasaan kehidupanya orang Batak bisa membicarakan segala macam masalah secara terbuka dan dan jujur serta mengambil keputusan secara tegas, hal ini juga diterapkan kepada anak-anak mereka sedari kecil. Anak-anak Batak diharuskan mempelajari tatacara adat mereka agar kelak mereka dapat meneruskanya.

Seringnya terjadi perkelahian di kampung subjek juga biasanya disebabkan oleh hal-hal kecil dan salah paham, karena mata saja bisa menjadi masalah. Karena mudah emosional maka ada kecenderungan berperilaku agresif, karena itulah timbul stereotipe yang menyatakan bahwa Etnis Batak kasar, mudah marah, emosional, dan agresif.

Dapatlah dilihat bahwa kehidupan subjek memang keras, ini sudah ditanamkan secara turuntemurun, bahwa setiap orang tua mengajarkan anaknya untuk mandiri, hal inilah yang membuat subjek tumbuh menjadi pribadi yang cenderung agresif, dengan lingkungan yang keras, dan didikan keluarga yang otoriter, sehingga dalam kehidupan sehari-hari perilaku yang ditimbulkan subjek adalah perilaku yang cenderung agresif. Perilaku itu timbul tidak dengan sendirinya, tetapi diikuti faktor-faktor pendukung seperti yang telah dijelaskan di atas. Dengan pribadi yang keras maka ketika beriems dengan situasi tidak menyenangkan subjek akan mudah untuk bertindak agresif.

Terjadinya kepatuhan hukum dapat disebabkan oleh hal-hal: (1) takut kena sanksi, (2) memelihara hubungan baik dengan pengusaha, (3) memelihara hubungan baik dengan rekan-rekan dalam kelompok, (4) terjaminnya kepentingan pribadi, (5) aturan hukum sesuai dengan nilai-nilai yang dianut.

Berdasarkan hasil wawancara terhadap informan dapat diidentifikasi faktor-faktor yang mempengaruhi tingkat kepatuhan hukum berlalu lintas pengemudi bus kota, adalah (1) faktor internal meliputi pengetahuan dan pemahaman para sopir yang rendah tentang ketentuan-ketentuan hukum, kurangnya kesadaran para sopir yang untuk mematuhi hukum yang berlaku, (2) faktor eksternal meliputi memadainya sosialisasi mengenai ketentuan-ketentuan hukum berlalu lintas dan angkutan jalan, perilaku penumpang yang mencari penumpang di luar terminal dan minta dijemput di alamat masing-masing, serta penegakan hukum oleh aparat (kepolisian, dinas perhubungan) tidak tegas.

\section{KESIMPULAN DAN SARAN}


Subjek melakukan perilaku agresi, baik secara verbal maupun fisik. Fisik, aktif, langsung, subjek sering terlibat dalam perkelahian dengan calo-calo yang tidak resmi ketika sedang mengemudikan bisnis Fisik, aktif. tidak langsung. Subjek suka menjulurkan bus dalam kecepatan tinggi serta menyalip mobil atau bus-bus lain, namun subjek dapat mengendalikan diri dan memikirkan keselamatan penumpang walau subjek hanya sedikit mengurangi kecepatan bus karena menurut subjek jika tidak demikian maka ia tidak bisa memenuhi uang setoran. Fisik, pasif, langsung, Subjek dalam mengendarai busnya sering menyalip bus lain hal ini juga dikarenakan subjek harus memenuhi uang setoran; Fisik, pasif, tidak langsung. Subjek suka mengendarai busnya dalam kecepatan tinggi; Verbal, aktif, langsung. Subjek suka mengeluarkan kata-kata kasar ketika sedang mengemudi ada bus lain menyalip atau mobil pribadi maupun motor, Verbal, aktif, tidak langsung. Subjek suka menyebarkan isu kepada calon penumpang bahwa busnya yang terakhir dan tidak ada bus lagi setelah itu, hal ini dilakukan dengan alasan agar subjek mendapatkan banyak penumpang, Verbal, pasif, langsung, Subjek terkadang tidak mempedulikan orang lain yang dianggapnya tidak perlu diladeni. Hal-hal yang memicu timbulnya perilaku agresi pada subjek adalah frustrasi, stres, deindividuasi, kekuasaan dan kepatuhan, provokasi dan suhu udara. Frustrasi, subjek mengalami frustrasi yang disebabkan karena banyaknya kebutuhan namun subjek tidak dapat memenuhi kebutuhan-kebutuhan tersebut; stres, subjek mengalami stres karena memburuknya keadaan ekonomi subjek sehingga memicu subjek untuk berperilaku agresi, deindividuasi, deindividuation mempeni peril agresi pada subjek, karena objek merasa yang mengendarai bus tersebut maka objek terkadang berperilaku mempertimbangkan keadaan penumpang, subjek harus memenuhi uang setoran yang ditetapkan oleh pemilik bi, oleh sebab itu subjek memenuhi setoran, provokasi, objek terkadan suka terprovokasi oleh perilaku penumpang ya membudaya emosional; suhu udara, suhu udara juga mempengaruhi perilaku agresi pada subjek, suhu udara yang panas memicu subjek berperilaku lebih agresi.

Tingkat kepatuhan hukum berlalu-lintas supir bisa kota beretnis Batak berada pada tingkat kepatuhan hukum yang masih rendah, dengan indikator bahwa, pengemudi mengetahui bahwa kegiatan menaikkan dan menurunkan penumpang disembatrang tempat, yang bukan halte pemberhentian dan keberangkatan penumpang, serta cara mengendari yang dapat membahayakan pengguna jalan lain. Faktor yang mempengaruhi tingkat kepatuhan para sopir bus kota adalah faktor kurangnya sosialisasi UULAJR dan ketidaktegasan aparat penegak hukum dalam memberikan sanksi, serta faktor kesadaran masyarakat sendiri atau penumpang. Tanggapan pengemudi sopir bus kota terhadap ketentuan UULAJR. masih sangat terbatas sebagian besar beranggapan bahwa jika kelengkapan surat-surat kendaraan sudah ada maka dianggap sudah mematuhi ketentuan UULAJR.

\section{REFERENSI}

Anwar, D. 2003. Kamus Lengkap Bahasa Indonesia. Jakarta : Penerbit Surabaya

Berkowitz, L. 1993. Aggression : Its Causes, Consequences, and Control. USA: McGraw Hill, inc. Breakwell, G.M. 1998. Mengatasi Perilaku Agresif. Yogyakarta : Penerbit Kanisius.

Daluay, A.S. 2004. Adat Budaya Batak Dalihan Na Tolu. http:// www.depdiknas.go.id/jurnal/35/adat_budaya batak dalihan na tolu.htm.

Deaux, K, Dane, F.C., Wrightsman, L.S., \& Sigelman, O.K. 1993. Social Psychology in The 90'. Sixth Edition $C A$ : Brooks / Cole Publishing Company.

EZ \& Aprilia. R. 2005. Kamus Lengkap Bahasa Indonesia. Jakarta: Penerbit Senja Difa Publisher Hall \& Lindzey. 1993. Teori-Teori Sifat dan Behavioristik. Yogyakarta : Penerbit Kanisius.

Hidayah, Z. 1997. Ensikopledi Suku Bangsa di Indonesia. Jakarta: LP3ES.

Jimmy, H.E.W. 2000. http://www.geocities.com/primbon2000/suku.htm 
Koentjaraningrat. 1981. Pengantar Antropologi. Jakarta : Penerbit Djambatan.

Koentjaraningrat. 2004. Manusia dan Kebudayaan di Indonesia. Jakarta Penerbit Djambatan.

Koeswara, E. 1988. Agresi Manusia. Jakarta: Penerbit Eresco.

Marshall, C \& Rossman, G. 1989. Designing Qualitative Research. California: Stage Publications, Inc.

Mertokusumo, Sudikno 2007, Mengenal Hukum Suatu Pengantar, ed.ke- 3 cet.ke-1. Yogyakarta: Liberty.

Moleong, L.J. 1996. Metode Penelitian Kualitatif. Bandung : PT. Remaja

Patton, M.Q. 1990. Qualitative Evaluation a Research Method editian. Newbury Park : Sage Publications

Peranginangin, M.L. 2004, Orang Karo Di antara Orang Batak. Jakarta : Pustaka Sara Mido.

Peraturan Pemerintah No. 41 Tahun 1993 tentang Angkutan Jalan

Poerwadarminta, WJS. 2003. Kamus Umum Bahasa Indonesia. Jakarta Balai Pustaka.

Poerwandari, E.K. 1998. Pendekatan Kualitas dalam Penelitian Psikologi. Jakarta : Penerbit. Universitas Indonesia

Pospisil L., Anthropology of Law, A Comparative Theory, Harper \& Row Publisher, London, 1971.

Rivanto. Y. 1996. Metodologi Penelitian. Surabaya : Penerbit SIC.

Riyanti, B.P.D \& Prabowo, H. 1998. Psikologi Umum 2: Seri Diktat Kuliah. Jakarta : Universitas Gunadarma

Salim, A.H.A. 1998, Manajemen Transportasi. Jakarta - Penerbit Rajagrafindo Persada,

Salim, M. A \& Salim. P. 2002. Kamus Bahasa Indonesia Kontemporer. Jakarta Modern English Press.

Salman, Otje. (1989). Beberapa Aspek Sosiologi Hukum. Bandung: Alumni

Santoso, A.A.R.A.L. 2000. Kamus Lengkap Bahasa Indonesia. Jakarta : Penerbit Alumni Surabaya

Sarwono, S.W. 1999. Psikologi Sosial:Individu dan Teori-teori Psikologi Sosial. Jakarta : Penerbit Balai Pustaka

Soekanto, Soerjono. 1986. Pengantar Penelitian Hukum. UI Press, Jakarta.

Suryadinata, L., Arifin, E.N., \& Ananta, A. 2003. Penduduk Indonesia Etnis dan Agama dalam Era Perubahan Politik. Jakarta : LP3ES.

Tim Prima Pena. 2005. Kamus Lengkap Bahasa Indonesia, Jakarta : Penerbit Gita Media Press.

Tutik, Titik Triwulan. 2006. Pengantar Ilmu Hukum. Surabaya : PT. Prestasi Pustaka.

Undang-Undang Nomor 22 Tahun 2009 Tentang Lalu lintas dan Angkutan Jalan

Van Aveldoorn. 1996. Pengantar Ilmu Hukum. Jakarta : PT. Pradanya Paramita.

Vargouwen, J.C. 1985. Masyarakat dan Hukum Adat Batak Toba. Penerbit: Pustaka Azet.

Warnaen, S. 2002. Stereotipe Etnis dalam Masyarakat Multietnis. Jakarta: Mata Bangsa

Wasis, W. 1998. Ensiklopedia Nusantara : Mengenal Tanah Air. Jakarta :Penerbit Mawar Gempita.

Yin, R.K. 2003. Studi Kasus Design dan Metode. Ed. Revisi. Jakarta : PT. Rajagrafindo Persada 


\section{Competing interests}

No conflict interest.

\section{Funding.}

None.

\section{Acknowledgements.}

Thank you to all those who have supported and helped this research.

\section{About the Authors}

The authors is a lecture at Universitas Nahdlatul Ulama Indonesia 